\title{
The Incremental Information Content of the Cash Flow Statement: An Australian Empirical Investigation
}

\author{
Hadri Kusuma ${ }^{1}$ \\ ${ }^{1}$ School of Accounting, Islamic University of Inindonesia, Indonesia \\ Correspondence: Hadri Kusuma, School of Accounting, Islamic University of Indonesia, Condong Catur, Depok, \\ Sleman, Yogyakarta, 55283, Indonesia. Tel: 62-27-488-1546. E-mail: hkusuma@uii.ac.id
}

Received: June 22, 2014

Accepted: July 4, 2014

Online Published: July 15, 2014

doi:10.5430/ijba.v5n4p90

URL: http://dx.doi.org/10.5430/ijba.v5n4p90

\begin{abstract}
The general objective of the present study is to investigate and assess the incremental information content of cash flow disclosures as required by the AASB 1026 "Statement of Cash Flows". This test addresses the issue of whether a change in cash flow components has the same relationship with security prices as that in earnings. Several previous studies indicate both income and cash flow statements may be mutually exclusive or mutually inclusive statements.

The data to test three hypotheses came from companies listed on the Australian Stock Exchange for the period of 1992 to 1997, a subsequent period of the requirement to apply AASB 1026. General results from hypothesis tests indicate that cash flows have information content more than that provided by earnings alone and that cash flows have relative information content, given earnings alone. This finding suggests that the cash flow statement and the income statement provide mutually exclusive information. This finding refutes results of previous studies from the USA and UK that indicated cash flow data had less information value than that conveyed by earnings. Other implications and suggestion for further study are also discussed in the paper.
\end{abstract}

Keywords: incremental, information, earnings, cash flow

\section{Introduction}

The statement of cash flows, the focus of this research, reports the amount of cash coming in and the amount of cash going out. In other words, the cash flow statement is a summary of cash receipts and cash payments for a specific period (Harrison and Horngren, 1995). In most countries including the USA, Australia and New Zealand it has superseded the "funds statement", which was often called The Statement of Sources and Application of Funds. The release of AASB 1026 as guidance for cash flow reporting seems to conform well with SAC 2 "Objectives of General Purpose Financial Reports" (GPFR) and SAC 3 "Qualitative Characteristics of Financial Information". Paragraph 45 of the SAC 2 states GPFR "shall disclose information relevant to the assessment of performance, financial position and financing and investing ...". This directive is followed by the discussion in paragraphs 29 to 40 about the type of information relevant to various user groups of financial information, including the information of cash flow data. SAC 3 emphasises the need for reliable cash flow data to make decisions about the allocation of scare resources.

Previous studies are concerned with the comparison between cash flow and earnings data to predict or generate future cash flows. The concern stems from the AASB contention that the cash flow statement should be read with other statements, particularly, the balance sheet and income statement. Unlike the balance sheet, the income statement has been the focus of attention by many researchers for many years. Dechow (1994) argued that earnings is the summary measure of a firm's performance that resulted from the accrual basis of accounting. Earnings is an important measure since it has been used by a wide range of users as the summary of firm performance. For example, it is utilised in debt covenants and by investors and creditors for the purpose of their investing and financing decisions. Also it is well documented that earnings has information content (e.g: Ball and Brown, 1968; Board and Day, 1989; and Charitou and Ketz, 1990).

Meanwhile, cash flow data have received serious attention in the last decade because the cash flow figure, like earnings, is expected to have ability in predicting future cash flows. Previous studies provide evidence consistent with this expectation (e.g: Ali and Pope, 1995 and Wilson, 1987). Thus, if both income and cash flow statements 
have information content, the question arises as to whether or not these two statements are mutually exclusive or inclusive. If the two statements are mutually inclusive, the information conveyed by cash flow statement (earnings statement) should be incremental to the information provided by earnings statement (cash flow statement). On the other hand, if both statements provide mutually exclusive information, then cash flow data (earnings figures) should have relative information to earnings figures (cash flow data) and thus both statements provide different information. Unfortunately, previous studies emphasised the incremental rather than relative information content. This suggests empirical evidence on this matter is needed to fill this gap. Therefore, the current study attempts to accomplish the general objective objectives of the study: to compare the ability of cash flows and earnings in predicting future cash flows. This test addresses the issue of whether a change in cash flow components has the same relationship with security prices as that in earnings.

\section{Theoretical Framework and Previous Studies}

\subsection{Incremental Information Content}

The term incremental information content became popular as a result and an extension of the studies on information content. Biddle et. al. (1995) provide an extensive explanation of the incremental information content. According to them, the term incremental information content is used to assess whether one accounting measure or a set of measures provides information content beyond that provided by another. This term applies when one or more accounting measures are considered as given and an assessment is desired regarding the incremental distribution of another. In accounting research, tests for incremental information content have been applied extensively to address questions such as the incremental information content of cash flows (earnings) beyond earnings (cash flows) and the incremental information content of additional financial disclosure (Biddle et. al., 1995).

In terms of statistical dependency, the incremental and the relative information content are a conditional statistical relationship between some accounting variables and security returns. The conditioning variables in this study are the component of cash flows and earnings. For example, say that historical cash flows (NetCF) consist of total cash flows from operations (Op), financing (Fin) and investment (Inv). The test for no incremental information content of operating cash flows (Op) may be represented by the following relationship:

$$
E\left(R_{j t} \mid O p, \text { Fin, Inv }\right)=E\left(R_{j t} \mid \text { Fin, Inv }\right)
$$

Where:

$$
\begin{aligned}
& R_{j t} \text { is security returns } \\
& E\left(R_{j t} \mid O p, \text { Fin, Inv }\right) \text { is expected value of } R_{j t} \text { given signal } O p, \text { Fin, and Inv and } \\
& E\left(R_{j t} \mid \text { Fin, Inv }\right) \text { is expected value of } R_{j t} \text { given signal Fin, Inv }
\end{aligned}
$$

The issue here is to test whether the additional variable, operating cash flows, changes the expectation of the security return distribution. Stated differently, do operating cash flows have information content if financing cash flows and investing cash flows hold constant? (Jennings, 1987). This is the general notion of the hypothesis adopted in this study to test the incremental information content of the component of cash flows and earnings.

\subsection{Evidence on Incremental Information Content of Cash Flows}

Ball and Brown (1968) conducted an early study that examined the relationship between earnings and cash flows, and security returns, by utilising the efficient market hypothesis. Their study is often considered to be the foundation of market-based accounting research today (Lev and Ohlson, 1982). The results indicated that earnings explain security prices significantly more than cash flows. However, Beaver and Dukes (1972) questioned the results of Ball and Brown due to the measurement of accounting earnings, which unfortunately had been a major concern of users of accounting data. Beaver and Dukes then investigated this relationship. The result of the Beaver and Dukes study is consistent with Ball and Brown's, that earnings had a significantly greater relationship to security returns than cash flow data. The consistent conclusion provided by these two studies, however, should be interpreted carefully for the following two reasons. First, the cash flow measure used was clearly subject to criticisms in the literature because of employing traditional cash flow measures, which were computed by adding back depreciation, amortisation and depletion to net income. Second, these studies did not test for incremental information content, but only tested relationships among the variables (Bowen, et. al., 1986). These studies reflected the thinking of the period by many users of accounting information that earnings were more meaningful than cash flow data. Therefore, these early studies seem to support the validity of FASB's notion that earnings are a better predictor and indicator of future earning than cash flow (Charitou, 1997).

Similar to Belkaoui (1982), Harmon (1984) used a ratio approach to test the superiority of earnings over cash. 
However, Harmon examined nine variables, rather than three variables, from income and cash-based accounting. The Cramer statistic was used to measure the relative strength of association between each variable and market reaction. The Cramer statistic indicated that all variables had a poor association with the market change but earnings were the superior variable. The short-term nature of the sample period is a major criticism of this study.

Since there are consistent results from the previous studies that earnings explain security prices, a number of studies were directed toward the content of earnings, mainly accruals. One study of this type is by Wilson $(1986,1987)$, who decomposed earnings into current accruals, non-current accruals, working capital from operations (fund flows), and cash flow from operations. He tested whether the components of accruals in general provided incremental information. The studies indicated that earnings accruals had information content beyond cash flows and that cash flows and accruals jointly had information beyond earnings alone. Similar studies by Rayburn (1986) and Lipe (1986) indicated a result consistent with Wilson's (1986) study.

Wilson's studies $(1986,1987)$ have also been criticised in the literature because it used only two quarters of data for the time periods, from 1981 to 1982. Bernard and Stober (1989) even doubted the validity and robustness of Wilson's studies. They then replicated the study by using data for over 32 quarters. Their study indicated that only in two-quarter periods was the result consistent with that of Wilson's, but there was no evidence for a similar result for the longer period of 1977-1984.

In addition to studies using a crude definition of cash flows, some studies attempted to use more refined definitions as suggested by Gombola and Ketz (1983) and Largay and Stickney (1980). Two refined definitions of cash flows were: the cash flow that was computed as working capital from operations plus decreases in current assets other than cash and increases in current liabilities, and the cash flows as in the former cash flow definition but excluding current maturities of long-debt. According to Gombola and Ketz (1983) the refined cash flow definition provided an earlier sign of financial distress than that did other financial ratios and earnings information. Largay and Stickney (1980) indicated that cash flow ratios contain information that is separate and distinct from earnings-based information.

Schaefer and Kennelley (1986) compared the incremental information content of these three cash flow measures over accrual earnings. The empirical result showed that accounting earnings provided information content beyond the various measures of cash flows and refined cash flow did not support greater association with stock prices. This result was consistent with Bowen et. al., (1987) but was contrary to results of Ismail and Kim (1989) that cash flows and fund flows had information beyond earnings. Barlev and Livnat (1990) also provided a consistent result with Schaefer and Kennelley even though Barlev and Livnat used a ratio approach. The study by Schaefer and Kennelley, however, suffered from limitations that prevent it from providing strong evidence of the importance of the cash flow. First, collinearity among independent variables occurred and thus incremental effects would not be expected. Another problem was the assumption underlying the study that the market reacts to the cash flow disclosures of pooled sample firms in a similar fashion to industrial and individual behavior.

At the beginning of the 1990s the most comprehensive study to examine the component of cash flows was undertaken by Livnat and Zarowin (1990). They doubted the previous studies that mostly emphasised operating cash flows. Livnat and Zarowin examined fourteen components of cash flows, including accruals, and revealed that operating cash inflows were positively associated with stock returns, but cash outflows were negatively associated with stock returns. When looking at individual components of cash flows, the result suggested that debt issue was positively associated, stock issue weakly but positively associated, and dividends positively associated with stock returns. In addition, when they disaggregated net income into operating cash flows and accruals, this disaggregating did not contribute to the associations with security returns beyond the contribution of net income alone. However, the disaggregation of financing and operating cash flows into their components improved the degree of association, which was not found with components of investing flows. Even though the results provided by Livnat and Zarowin were robust, the study still had a limitation: that is, the use of crude proxies of cash flow components. This weakness occurred because of data from pre-SFAS No.95 that was introduced in 1987. However, the study was an initial comprehensive examination of the cash flow components, as a contrast to most of the previous studies concentrating only on the operating cash flows.

Unlike previous studies which employ returns as the measure of a firm's value, Charitou and Ketz $(1990,1991)$ used cross-sectional valuation in testing the association of cash flows from operating, financing and investing activities with the market values of the firm. In particular, Charitou and Ketz employed the CAPM approach by extending the work of Rayburn (1986) and Wilson $(1986,1987)$. In these two studies, Charitou and Ketz defined the value of information as a statistical relationship between accounting data and security prices. With 403 firms in the sample from Compustat and Centre for Research in Securities Price Database for the period 1968 to 1985, the 1991 study 
found that accrual and cash flow components of earnings were valued in the market place. More specifically, cash flow information from operations, cash available for dividends and cash available for investments were associated with positive price movements. The 1990 study by Charitou and Ketz, however, indicated that earnings were valued more than cash flows, and cash flows and accruals provide equal information in explaining security prices. Similar result was given by Ingram and Lee (1997); and Ali (1994) that used both linear and non-linear relationships when examining the incremental information content of earnings, working capital from operations and cash flows.

At the end of 1997, Cheng, Liu and Schaefer (1997) assessed the importance of the cash flow statement as required by FASB no.95. The motivation for this study is that previous studies did not provide consistent evidence on the incremental information content of cash flows and they used estimated rather than reported cash flows. These estimated cash flows, according to them, are noisy. In this study, Cheng, Liu and Schaefer found the estimated cash flows fail to show significant market effects after actual FASB no.95 disclosures are included in the analysis. Inversely, the reported cash flows continued to have information content in market association beyond estimated cash flows from operations. Cheng, Liu and Schaefer (1997) concluded cash flows from operations are relevant disclosures for investment. Thus, this study supports FASB no.95 "Statement of Cash Flows". The focus on cash flows from operations may be the serious limitation of this study. Simons (1992); Charitou and Vafeas (1998); and Board and Day (1989) provided similar conclusion to the study of Cheng, Liu and Schaefer (1997).

However, Ali and Pope (1995) doubted the validity of the three performance measures employed by Board and Day (1989). Ali and Pope extended Board and Day's study by incorporating some recent innovations in the specifications of earnings-returns model. Ali and Pope (1995) found results inconsistent with Board and Day: that is, cash flows had value-relevant incremental information for equity investors beyond earnings and funds flow. In a similar study, Charitou (1997) strengthened the result of Board and Day, particularly when incorporating the operating cycle, magnitudes of accruals and measurement interval in the cash flow-return relationship.

In Australia, studies that examined the association of cash flows and earnings with security prices have also received attention recently. Cotter (1996) used the empirical framework developed by Easton, Harris and Ohlson (1992) and was the first in Australia. Similar to the overseas studies, Cotter employed crude measures of cash data. She compared components of clean surplus accrual earnings with those of total cash flows to assess their relative ability to recognise value relevant events in a timely manner. The study revealed that the association between stock returns and earnings was higher than that with total cash flows. Further, even though cash flows from operations and current accruals were able to recognise value relevant events in a timely manner, cash flows from financing and investing activities were of less value relevance for longer return intervals. Evidence provided by Seng (1996), and Chia, Czernkowski and Loftus (1997) show a result consistent with Cotter's study. In addition, even though Chia et. al. used a different approach from that of Cotter (a cross-sectional method, with data for period 1985 to 1990), they found cash flow from operations had information content in relation with stock returns.

These studies are important for the Australian accounting profession because the studies provide evidence after the adoption of AASB 1026 since 1992. In particular, these two studies in Australia provide a lack of support for implementing cash flow statements under AASB 1026. However, there may be some explanations for this deficiency of information content of cash flows. First, Cotter (1986) and Chia et. al. (1997) employed crude measures of cash flow definition. Second, the data used in these studies were extracted from financial statements before the introduction of AASB 1026 and thus employed estimated rather than reported measures. Third, the study of Cotter (1996) used a small sample size and Chia et. al. (1997) only employed the top 500 companies on the Australian Stock Exchange.

There is extensive US evidence on cash flows. Some studies on this matter have also received attentions in the UK, Australia, and New Zealand. In general, previous studies indicate that cash flow data may have information content and incremental information content, but there is dominant evidence that the information content of earnings is beyond that of cash flows. However, the empirical support for the usefulness of cash flow data in predicting future cash flows above must be interpreted with caution in view of limitations and criticisms. First, studies by Rayburn (1986), Bowen et. al. (1986 and 1987), Wilson (1986), Charitou and Ketz (1991), and Cotter (1996) treated all firms in one sample. This treatment assumed that small firms behave in the same manner as large companies and vice versa, and thus the relationship between earnings, cash flows and returns is assumed to be homogeneous across firms (Charitou, 1997).

Second, the previous studies illustrated the weak explanatory power of the previous models used and the instability of the earnings and cash flow response coefficients (Charitou, 1997). Collins and Kothari (1989), and Easton and Zmijewski (1989) demonstrated that the response coefficients can be influenced by firm characteristics, such as firm 
size, industry classification, capital structure, length of operating cycle, measurement interval, and quality of earnings.

Finally, these previous studies generally emphasise a certain component of cash flows, namely operating cash flows or the aggregate of cash flows. These studies also focus on incremental rather than relative information content. Nevertheless a comprehensive study assessing the predictive ability of cash flow components on security returns after the enactment of cash flow accounting standards such as AASB 1026 has not been explored. In addition, a study that examines whether cash flow disclosures have both incremental and relative information content, given earnings figures, is scarce. This study addresses the above issues.

\subsection{Hypotheses}

The objective of the current study is to compare the ability of cash flows and earnings in predicting future cash flows. The issue addressed here is whether two sources of information (cash flow statement and income statement) provide information in predicting future cash flows jointly or individually. The following hypotheses are constructed to test this issue.

$$
\begin{aligned}
& H_{1}: \text { Historical cash flows do not have incremental information content beyond that provided by earnings } \\
& \text { alone. } \\
& H_{2} \text { : Total operating, investing and financing cash flows do not have incremental information content } \\
& \quad \text { beyond that provided by earnings alone. } \\
& H_{3}: \text { The components of total operating, investing and financing cash flows do not have incremental } \\
& \text { information content beyond that provided by earnings alone. }
\end{aligned}
$$

\section{Research Method}

\subsection{Data}

The target population in this study is all companies listed on the Australian Stock Exchange (ASX) which meet the following criteria:

1. firms must have a June 30 fiscal year,

2. data for firm cash flows and earnings must be available in Datadisc files, and

3. yearly data for share prices of the firms must be available in the Bloomberg database.

The first criterion is intended to maintain the similarity of the data events. The second and third criteria respectively are to ensure the consistency of data in calculating the stock returns and the availability of accounting data. Failure to use these criteria may cause overlapping annual return windows and lack of independence of regression residuals across years with the consequence of bias in cross-temporal t-statistics from the year analysis (Ali and Pope, 1995).

\subsection{Definition and Measurement of Variables}

The dependent variable employed for all multiple regression models in this study is the security returns. The security return calculation is defined as the price per share at the end of current year minus the price per share of the previous year plus dividend per share during the year, divided by the price per share of the previous years (Chia et. al., 1997). Mathematically, the equation to calculate security returns $\left(\mathrm{R}_{\mathrm{jt}}\right)$ is:

$$
R_{j t}=\frac{\left(\mathrm{P}_{\mathrm{jt}}-\mathrm{P}_{\mathrm{jt}-1}\right)+\mathrm{D}_{\mathrm{jt}}}{\mathrm{P}_{\mathrm{jt}-1}}
$$

Where,

$R_{j t}$ is the annual return for firm $j$ at the current year (time $t$ )

$P_{j t}$ is security price of firm $j$ at the current year (time $t$ )

$P_{j t-1}$ is security price of firm $j$ at the previous year (time $t-1$ )

$D_{j t}$ is the dividend paid on security $j$ at the current year (time $t$ )

This study uses the AASB definition of components of cash flows in selecting the variables in the models. The components of cash flows are classified as cash flows from operating, investing and financing activities. According to AASB 1026 (paragraph 9),

"Cash flows from financing activities include proceeds from issuing equity instruments and outlays to buy 
back such instruments; proceeds from short-term or long term-term borrowing and repayments of borrowing; and payments of dividends".

"Cash flows from investing activities include payments to acquire property, plant and equipment, and proceeds from the sale of such assets payments to acquire equity instruments of other companies, and proceeds from the sale of such instruments; and other equity contributions, for example, acquisition of an ownership interest in a partnership".

"Cash flows from operating activities include payments to suppliers and employees for goods and service; and receipts in respect of the provision of goods and services".

Given this definition, the variables of cash flows in this study are depicted in Table 1 . These variables of cash flows are similar to those employed by Livnat and Zarowin (1990) and Cotter (1996), but this study differs because the present study uses reported rather than estimated cash flow data.

Net income is defined as net income after tax but before extraordinary items. This definition conforms to "AASB 1018: Profit and Loss Account". This definition was used in the study by Chia et. al. (1997). Similar to cash flows variable, earnings is on per share basis but deflated by the per share price as shown in Table 1.

Table 1. Variables used in the regression equations

\begin{tabular}{|c|c|}
\hline Description & Notations \\
\hline $\begin{array}{l}\text { Independent Variables: } \\
\text { Operating cash flows } \\
\text { - Cash received from customers, } \\
\text { - Cash paid to suppliers, employees and others, } \\
\text { - Cash paid for taxes, } \\
\text { - Net cash paid for interest, } \\
\text { - Net cash flow from other operating activities, } \\
\text { - }\end{array}$ & $\begin{array}{l}\mathrm{Cst}_{\mathrm{jt}} \\
\mathrm{Spp}_{\mathrm{jt}} \\
\mathrm{Tx}_{\mathrm{jt}} \\
\mathrm{Int}_{\mathrm{jt}} \\
\mathrm{Othop}_{\mathrm{jt}} \\
\mathrm{AgOp}_{\mathrm{jt}}\end{array}$ \\
\hline $\begin{array}{l}\text { Investing cash flows } \\
\text { - Cash used from new investment in property, plant, and equipment, } \\
\text { - Cash obtained from the sale of investment in property, plant and equipment, } \\
\text { - Cash used for the acquisition of new business, } \\
\text { - } \quad \text { Aggregate investing cash flows. }\end{array}$ & $\begin{array}{l}\operatorname{Uinv}_{\mathrm{jt}} \\
\operatorname{Obinv}_{\mathrm{jt}} \\
\operatorname{Acqb}_{\mathrm{jt}} \\
\operatorname{AgIn}_{\mathrm{jt}}\end{array}$ \\
\hline $\begin{array}{l}\text { Financing cash flows } \\
\text { - Cash received from new issuance of debts, } \\
\text { - Cash used for payment of debts, } \\
\text { - Cash received from issuing new common and preferred stocks, } \\
\text { - Cash paid for dividend, } \\
\text { - } \quad \text { Aggregate financing cash flows. }\end{array}$ & $\begin{array}{l}\text { Obdebt }_{j t} \\
\text { Pdebt }_{j t} \\
\text { Iseq }_{j t} \\
\text { Dev }_{j t} \\
\text { AgFin }_{j t}\end{array}$ \\
\hline $\begin{array}{l}\text { - Historical cash flows are the sum of aggregate operating, investing, and financing } \\
\text { cash flows }\end{array}$ & $\operatorname{NetCf}_{\mathrm{jt}}$ \\
\hline - Earning per share scaled by price per share at the beginning of the year & $\mathrm{E}_{\mathrm{jt}}$ \\
\hline $\begin{array}{l}\text { Dependent Variables } \\
\text { - Annual return of a company } j \text { at time } t\end{array}$ & $R_{i t}$ \\
\hline
\end{tabular}

\subsection{Empirical Design}

This study employs three regression models to test hypotheses identified in the earlier section as follows.

$$
\begin{gathered}
R_{j t 5}=\varphi_{0}+\varphi_{1} \operatorname{NetCf}+\phi_{1} E+w_{j} \\
R_{j t 6}=\chi_{0}+\chi_{1} A g O p+\chi_{2} A g F i n+\chi_{3} A g I n+\phi_{2} E+v_{j}
\end{gathered}
$$




$$
\begin{aligned}
R_{j t 7}= & \delta_{0}+\delta_{I} C s t+\delta_{2} \text { Spp }+\delta_{3} \text { Tx }+\delta_{4} \text { Int }+\delta_{5} \text { Othop }+\delta_{6} \text { Uinv }+ \\
& \delta_{7} \text { Obinv }+\delta_{8} \text { Acqb }+\delta_{9} \text { Obdebt }+\delta_{10} \text { PDebt }+\delta_{11} \text { Iseq }+ \\
& \delta_{12} \text { Dev }+u_{j}
\end{aligned}
$$

Where,

$\varphi, \chi$, and $\delta$ are estimated parameters,

$w, v$, and $u$ are random disturbances and the other variables are defined in Table 1

\section{Results and Discussions}

\subsection{Descriptive Statistics}

Table 2 in the appendix provides distributional information and the descriptive statistics for the six years under the study (1992-1997). Table 2 shows the descriptive statistics for returns, earnings, and components of cash flows when cash flows are deflated by market equity of firms.

Table 2. Selected descriptive statistics

\begin{tabular}{lccccccccc}
\hline Statistics & RR & E & Netcf & \multicolumn{1}{l}{ Agop } & \multicolumn{1}{l}{ Agin } & \multicolumn{1}{l}{ Agfin } & \multicolumn{1}{l}{ Cst } & \multicolumn{1}{l}{ Spp } & Tx \\
\hline Means & 0.4358 & 0.1001 & 0.0461 & 0.1590 & 0.0061 & -0.1187 & 3.6380 & -3.3745 & -0.0385 \\
Median & 0.1295 & 0.0080 & 0.0020 & 0.0373 & -0.0630 & 0.0110 & 0.3869 & -0.3526 & 0.0000 \\
Std Dev & 1.6840 & 2.1225 & 1.7574 & 2.9278 & 8.3094 & 6.8899 & 40.6857 & 37.6371 & 0.6334 \\
Minimum & -22.0000 & -3.7735 & -23.2775 & -25.3040 & -252.3990 & -334.1760 & -0.4774 & -1259.5400 & -33.3739 \\
Maximum & 45.6667 & 117.8427 & 85.0980 & 145.2461 & 376.8747 & 106.0548 & 1402.8540 & 0.7606 & 0.5836 \\
\hline & & & & & & & & & \\
\hline Statistics & Int & Othop & Uinv & Obinv & Acqb & Iseq & Obdebt & Pdebt & Dev \\
\hline Means & -0.0731 & 0.0071 & -0.3918 & 0.4803 & -0.0865 & 0.1715 & 0.3277 & -0.5695 & -0.0434 \\
Median & 0.0000 & 0.0000 & -0.1016 & 0.0119 & 0.0000 & 0.0026 & 0.0000 & -0.0043 & 0.0000 \\
Std Dev & 1.1725 & 0.2874 & 2.5305 & 7.5813 & 4.1063 & 1.9570 & 6.5709 & 8.7295 & 0.5580 \\
Minimum & -38.5543 & -3.9135 & -122.5450 & -3.5496 & -237.3750 & -1.2549 & -38.1122 & -332.2990 & -31.1295 \\
Maximum & 18.7857 & 7.0552 & 1.5176 & 389.0614 & 0.0869 & 108.4793 & 361.0035 & 6.6137 & 0.3556 \\
\hline
\end{tabular}

\subsection{Hypothesis Tests}

This section reports the results from performing the tests of the hypotheses of cash flows versus earnings. Three original sets of cash flows were tested: historical cash flows (NetCF), aggregate cash flows from operating, investing and financing activities (AgOp, OgIn and AgFin), and detailed components of cash flows (Cst, Spp, Tx, ... Dev). These three sets of cash flows are tested against earnings. Earnings is used as a benchmark because the information content of this variable is well known in the literature.

\subsubsection{Historical Cash Flows and Earnings}

The issue addressed in hypothesis 1 here is whether historical cash flows have incremental information value to predict future cash flows after controlling for earnings. The incremental information content of the historical cash flow is inferred when the coefficient of historical cash flows $\left(\varphi_{1}\right)$ in equation 1 is significant. Table 3 presents the results of the tests. Table 3 indicates that earnings and historical cash flows jointly have information value to predict future cash flows. F-values for pooled data are significant at the $1 \%$ level. Cross-sectional F-values also support this result.

Table 3 indicates that the coefficient of historical cash flows is significant for three years, implying incremental information content of cash flows. The coefficient of earnings (E), on the other hand, is significant in three years. Since year by year results provide significant coefficients, then it can be concluded that historical cash flows have incremental information content beyond that provided by earnings alone.

In summary, the main issue addressed in hypothesis six is to test whether historical cash flows reflect the information 
used by investors to price securities, conditional on investors knowing earnings information. The evidence in general indicates that historical cash flows possess (NetCF) incremental information content beyond that provided by earnings alone (E). There is also evidence that historical cash flows and earnings jointly can be used to predict future cash flows.

\subsubsection{Total Operating, Investing and Financing Cash Flows and Earnings}

This section presents the tests on hypothesis two. Hypothesis two tests incremental information content of three components of cash flows after controlling for earnings (AgOp, AgIn, AgFin, and E). The issue addressed by hypothesis is whether any of the three categories of cash flows provide incremental information content, given the information of earnings (equation 2). The null hypothesis is rejected when the coefficients of the cash flow variables are significant, implying incremental information content. Table 4 presents this test.

Table 3. Results of Hypothesis 1

\begin{tabular}{lccccccc}
\hline Variables & 1992 & 1993 & 1994 & 1995 & 1996 & 1997 & Pooled \\
Intercept $\left(\hat{\varphi}_{0}\right)$ & .692680 & .745081 & .475616 & -.139104 & .417660 & .286221 & .419366 \\
\hline NetCF $\left(\hat{\varphi}_{1}\right)$ & -.035741 & $.960625^{* * *}$ & $.603532^{* * *}$ & .038525 & .098143 & $.385072^{* *}$ & .012948 \\
$\quad$ Std. Error $)$ & $(.1060)$ & $(.1098)$ & $(.2085)$ & $(.0822)$ & $(.0630)$ & $(.1588)$ & $(.0158)$ \\
E $\left(\hat{\phi}_{1}\right)$ & $-.507586^{*}$ & -.419461 & .223168 & $.455289^{* * *}$ & .204258 & $.351139^{* *}$ & $.112846^{* *}$ \\
$\quad($ Std. Error $)$ & $(.2981)$ & $(.2702)$ & $(.2243)$ & $(.1155)$ & $(.2551)$ & $. .1538)$ & $(.0466)$ \\
F-value & 1.637 & $38.853^{* * *}$ & $4.771^{* * *}$ & $8.159^{* * *}$ & 1.515 & $6.668^{* *}$ & $3.214^{* *}$ \\
Adj-R & .0032 & .1416 & .0147 & .0229 & .0015 & .0163 & .0013 \\
$\mathrm{~N}$ & 395 & 460 & 506 & 613 & 668 & 683 & 3336 \\
\hline
\end{tabular}

* Significant a the $10 \%$ level

** Significant a the $5 \%$ level

*** Significant a the $1 \%$ level

Table 4. Results of Hypothesis 2

\begin{tabular}{lccccccc}
\hline Variables $^{\mathrm{a}}$ & 1992 & 1993 & 1994 & 1995 & 1996 & 1997 & Pooled \\
\hline Intercept $\left(\hat{\lambda}_{0}\right)$ & .582797 & .647513 & .5383 & -.176531 & .298241 & .240212 & .345521 \\
$\mathrm{E}\left(\phi_{2}\right)$ & -.384058 & $-.494596^{* *}$ & .138494 & 0.099451 & .232772 & $.200319^{*}$ & -.050943 \\
(Std. Error $)$ & $(.2797)$ & $(.2564)$ & $(.2457)$ & $(.1260)$ & $(.1990)$ & $(.1165)$ & $(.0410)$ \\
AgOp $\left(\hat{\lambda}_{1}\right)$ & $.354804^{* *}$ & $1.035412^{* * *}$ & .066314 & $.680122^{* * *}$ & $.955306^{* * *}$ & $.623042^{* * *}$ & $.706830^{* * *}$ \\
(Std. Error) & $(.1424)$ & $(.1069)$ & $(.1679)$ & $(.1577)$ & $(.2240)$ & $(.1383)$ & $(.0625)$ \\
AgIn $\left(\hat{\lambda}_{2}\right)$ & -.025513 & -.080318 & -.032869 & -.106295 & .128459 & $.380659^{* * *}$ & $.333750^{* * *}$ \\
(Std. Error) & $(.1131)$ & $(.1994)$ & $(.1251)$ & $(.1088)$ & $(.1603)$ & $(.1374)$ & $(.0593)$ \\
AgFin $\left(\hat{\lambda}_{3}\right)$ & .040387 & $1.027216^{* * *}$ & -.029423 & .149624 & $.888815^{* * *}$ & $.405088^{* * *}$ & $.542870^{* * *}$ \\
Std. Error) & $(.0955)$ & $(.1050)$ & $(.1598)$ & $(.1069)$ & $(.1413)$ & $(.1192)$ & $(.0545)$ \\
F-value & $4.534^{* * *}$ & $29.697^{* * *}$ & .517 & $16.085^{* * *}$ & $20.911^{* * *}$ & $7.604^{* * *}$ & $49.590^{* * *}$ \\
Adj-R & .0348 & .1994 & -.0038 & .0900 & .1074 & .0375 & .0554 \\
$\mathrm{~N}$ & 393 & 462 & 510 & 611 & 663 & 679 & 3314 \\
\hline
\end{tabular}

* Significant a the $10 \%$ level

** Significant a the 5\% level

*** Significant a the $1 \%$ level 
Table 4 reports F-values of equation 2 and indicates that they are very strong at the $1 \%$ level. The significance of the F-values suggests that the three components of cash flows and earnings are useful in explaining security returns. Table 4 further indicates that using pooled data the coefficients of operating, investing and financing cash flows $\left(\hat{\lambda}_{1}\right.$, $\hat{\lambda}_{2}, \hat{\lambda}_{2}$ ) are strongly significant at the $1 \%$ level. The coefficient of earnings, on the other hand, is not significant. Therefore, total operating, investing and financing cash flows possess incremental information content beyond that provided by earnings alone. Earnings do not have incremental information content beyond that given by the three components of cash flows.

The present results may be comparable to many previous studies. To recall, Cheng et. al. (1997) found that cash flows from operations have significant incremental explanatory power after controlling earning information. Clubb (1996), on the other hand, found accounting earnings data possess information content beyond cash flows from operations. Ali and Pope (1996) found earnings, working capital and cash flows from operations have incremental information content. Ali (1994) reported earnings have incremental information content beyond working capital and cash flows from operations, working capital from operations have incremental information content beyond earnings and cash flows from operations, and cash flows from operations do not have incremental information content beyond working capital and earnings. Lastly, Bowen et. al. (1987) found cash flows from operating and investing have incremental information beyond that contained by earnings. The incremental information content found in the present study supports the findings by Cheng et. al. (1997) and Bowen et. al. (1987) but is in contrast to Clubb (1996) and Ali (1994).

\subsubsection{Detailed Components of Cash Flows and Earnings}

This section presents the incremental information contents of detailed components of cash flows. The hypothesis is that the components of total operating, investing and financing cash flows (Cst, Spp, Tx ..., Dev) have no incremental information content beyond that provided by earnings alone. The null hypothesis is rejected if the coefficients of the cash flow are significant from zero. Table 5 presents results of hypothesis three.

Table 5 indicates that for the pooled data the components of cash flows together with earnings have significant F-values for all years at the $1 \%$ level. The cross sectional data supports the result of the pooled data. The significance of F-values implies that earnings and components of cash flows together have ability to predict future cash flows. Table 5 also indicates that all the components of cash flows possess incremental information content at least at the $10 \%$ level, implying the null hypothesis is rejected. The cross-sectional data in general supports the presence of information content of cash flows components on the pooled data.

For the cross-sectional data, the components of the operating activities in Table 5 indicate that coefficients of cash flows from customers (Cst) and for suppliers (Spp) are significant (1993, 1994, 1995, and 1997). Cash flow coefficients from other operating activities (Othop) are significant in 1994, 1995, 1996, and 1997. While the coefficient of cash flows for tax payment (Tx) is significant for two years, cash flow coefficient for interest (Int) is not significant in any single year. In investing activities, both the coefficients of cash used (Uinv) and obtained (Obinv) from investment are significant in 1993. The coefficient of cash flows from acquisition of new business (Acqb) is significant in 1997. In financing activities, net cash received from issuing new securities (Iseq) is strongly significant from zero at the $1 \%$ level for all years under the study. This is in contrast to cash paid for debt (Pdebt) and dividend (Dev) that are only significant in 1994 and 1993 respectively. The coefficient of cash inflows from obtained new debts (Obdebt) is significant for two years.

Table 5. Results of Hypothesis 3

\begin{tabular}{lccccccc}
\hline Variables ${ }^{\mathrm{a}}$ & 1992 & 1993 & 1994 & 1995 & 1996 & 1997 & Pooled \\
\hline Intercept $\left(\hat{\delta}_{0}\right)$ & .259999 & .525021 & .330337 & -.238042 & .167470 & .011766 & .209837 \\
$\mathrm{E}\left(\hat{\phi}_{3}\right)$ & -.114779 & -.054441 & .326629 & $.221393^{* *}$ & $.602202^{* * *}$ & $.367210^{* * *}$ & $.123067^{* *}$ \\
$($ Std. Error$)$ & $(.2498)$ & $(.2757)$ & $(.2385)$ & $(.1044)$ & $. .2043)$ & $(.1010)$ & $(.0596)$ \\
Cst $\left(\hat{\delta}_{1}\right)$ & .122212 & $.530400^{* * *}$ & $.265664^{* *}$ & $.420888^{* * *}$ & .004091 & $.401757^{* * *}$ & $.077334^{* *}$ \\
(Std. Error) & $(.1554)$ & $(.1453)$ & $(.1093)$ & $(.1231)$ & $(.1816)$ & $(.1300)$ & $(.0305)$ \\
Spp $\left(\hat{\delta}_{2}\right)$ & .145732 & $.526896^{* * *}$ & $.248093^{* *}$ & $.425528^{* * *}$ & -.009114 & $.392886^{* * *}$ & $.065041^{* *}$ \\
(Std. Error) & $(.1653)$ & $(.1484)$ & $(.1105)$ & $(.1233)$ & $.1815)$ & $(.1296)$ & $(.0310)$ \\
Tx $\left(\hat{\delta}_{3}\right)$ & 2.257689 & 1.687821 & $-3.34065^{* *}$ & .314176 & 1.011777 & $-2.03567^{*}$ & $2.787167^{* * *}$ \\
$(\operatorname{Std}$. Error$)$ & $(1.5433)$ & $(1.3981)$ & $(1.5519)$ & $(.7318)$ & $(1.3731)$ & $(1.0582)$ & $(.3021)$ \\
Int $\left(\hat{\delta}_{4}\right)$ & -.173433 & .413661 & -.507828 & .148467 & -.079954 & .691890 & $-.357348^{* * *}$
\end{tabular}




\begin{tabular}{lccccccc} 
(Std. Error) & $(.2330)$ & $(.3607)$ & $(.5030)$ & $(.3674)$ & $(.5681)$ & $(.5526)$ & $(.0450)$ \\
Othop $\left(\hat{\delta}_{5}\right)$ & -.123087 & .564737 & $.714177^{* * *}$ & $.486285^{* *}$ & $-.770617^{* *}$ & $.381645^{* *}$ & $.231647^{* * *}$ \\
(Std. Error) & $(.1834)$ & $(.2690)$ & $(.1816)$ & $(.1972)$ & $(.3381)$ & $(.15085)$ & $(.0826)$ \\
Uinv $\left(\hat{\delta}_{6}\right)$ & -.175355 & $-.490255^{* *}$ & .055921 & -.095259 & .042846 & .126988 & $-.074496^{* * *}$ \\
(Std. Error) & $(.1398)$ & $(.2229)$ & $(.0773)$ & $(.0740)$ & $(.1117)$ & $(.1334)$ & $(.0286)$ \\
Obinv $\left(\hat{\delta}_{7}\right)$ & .045956 & $-.537270^{* *}$ & $.108490^{*}$ & -.046484 & .0888679 & .140244 & $.048575^{* * *}$ \\
(Std. Error) & $(.1262)$ & $(.2259)$ & $(.0588)$ & $(.0724)$ & $(.1054)$ & $(.1292)$ & $(.0165)$ \\
Aqcb $\left({ }^{*}\right)$ & 2.676041 & 1.009965 & .495940 & .117454 & -.610593 & $-.939550^{* * *}$ & $-.445225^{*}$ \\
(Std. Error) & $(1.8633)$ & $(.8822)$ & $(.5111)$ & $(.2786)$ & $(.6367)$ & $(.3474)$ & $(.2404)$ \\
Obdebt $\left(\hat{\delta}_{9}\right)$ & -.007022 & .226020 & $.183079^{* *}$ & $.234330^{* *}$ & .040455 & .164527 & $.046865^{*}$ \\
(Std. Error) & $(.1093)$ & $(.2147)$ & $(.0827)$ & $(.1081)$ & $(.0813)$ & $(.1394)$ & $(.0243)$ \\
Pdebt $\left(\hat{\delta}_{10}\right)$ & .032046 & .256712 & $.206658^{* * *}$ & .075008 & .085767 & .022018 & $.088328^{* * *}$ \\
(Std. Error) & $(.0895)$ & $(.2055)$ & $(.0792)$ & $(.1272)$ & $(.0920)$ & $(.1650)$ & $(.0222)$ \\
Iseq $\left(\hat{\delta}_{11}\right)$ & $2.026053^{* * *}$ & $1.785806^{* * *}$ & $.755005^{* * *}$ & $.505998^{* * *}$ & $1.556775^{* * *}$ & $1.173956^{* * *}$ & $.596818^{* * *}$ \\
(Std. Error) & $(.1911)$ & $(.1954)$ & $(.1181)$ & $(.1239)$ & $(.1726)$ & $(.1456)$ & $(.0469)$ \\
Dev $\left(\hat{\delta}_{12}\right)$ & $-3.15971^{* * *}$ & -.193748 & $2.74741^{*}$ & -.26870 & $-1.28895^{*}$ & -.42665 & $-2.75557^{* * *}$ \\
(Std. Error) & $(.9670)$ & $(1.0323)$ & $(1.4618)$ & $(.5673)$ & $(.6645)$ & $. .5875)$ & $(.2394)$ \\
F-value & $13.878^{* * *}$ & $13.288^{* * *}$ & $7.904^{* * *}$ & $7.122^{* * *}$ & $9.923^{* * *}$ & $10.716^{* * *}$ & $40.335^{* * *}$ \\
Adj-R ${ }^{2}$ & .3020 & .2582 & .1499 & .1163 & .1489 & .1578 & .1330 \\
$\mathrm{~N}$ & 388 & 460 & 510 & 606 & 664 & 675 & 3334 \\
\hline
\end{tabular}

* Significant a the $10 \%$ level

** Significant a the $5 \%$ level

*** Significant a the $1 \%$ level

Table 6. Comparison of mean square errors of 3 equations

\begin{tabular}{lccr}
\hline \multicolumn{3}{c}{ Years } & \multicolumn{3}{c}{ Models of Cash Flows and Earnings } \\
\cline { 2 - 5 } & $2 \mathrm{CFE}^{\mathrm{a}}$ & $4 \mathrm{CFE}^{\mathrm{b}}$ & $13 \mathrm{CFE}^{\mathrm{c}}$ \\
1992 & 3.38891 & 2.65928 & 1.60509 \\
1993 & 2.27326 & 2.11428 & 1.96714 \\
1994 & 1.43069 & 1.71317 & 1.41147 \\
1995 & 0.44837 & 0.41843 & 0.24411 \\
1996 & 2.33961 & 1.33835 & 1.30333 \\
1997 & 1.21165 & 0.65806 & 0.45500 \\
Pooled & 2.55414 & 1.48043 & 1.08614 \\
\hline
\end{tabular}

a is equation 1

$\mathrm{b}$ is equation 2

$\mathrm{c}$ is equation 3

\subsection{Competing Models}

To choose the best model among these equations, the model that produces the lowest mean squared errors (MSE) is rated as superior. Table 6 indicates that among models of cash flows plus earnings (equation 1,2, and 3), equation 3 has the lowest mean square errors (MSE). For example, the pooled data has an MSE of 1.08614. Cross-sectional data in general also provide results consistent with the pooled data. Low MSE implies that the model has less dispersion around the true value of a parameter and results in a smaller residual component.

\section{Conclusions and Implications}

As stated in the introduction, the main purpose of the current study is to compare the ability of cash flows and earnings in predicting future cash flows. Looking at the significant coefficient of earnings in the models, in general there is little evidence that earnings have incremental information content. Therefore, it is concluded here that cash 
flows have incremental information content more than earnings alone.

The finding that cash flows can be used to predict future cash flows should be of major interest to the accounting standard setting body, namely AASB. The AASB states that "the information provided in a statement of cash flows together with other information in the accounts or consolidated accounts may assist in assessing the ability of a company or an economic entity to generate net cash flows in the future ... (AASB 1026, 1991, paragraph v,)". Further, AASB 1026 states the statement of cash flows was designed to meet the demand of the main users of financial statements. The findings of the present study justify AASB 1026s' requirement that reporting entities report their cash inflows and outflows at the end of a certain period. The findings also strongly support the claim made by AASB 1026. The findings of the present study suggest cash flow data are a good indicator of future cash flows.

Evidence on incremental information content of cash flows beyond that provided by earnings has implications for reporting entities in Australia. Since the accounting policy decisions on financial reporting issues can have potentially severe economic consequences, evidence of the present study may suggest that the benefits of providing cash flow information by reporting entities may exceed the derived costs. The findings may also suggest that reporting entities disclosed their cash flow statements in a timely manner. The finding in the present study, also suggests that creditors and investors can use not only earnings but also cash flows to predict future cash flows of companies.

Evidence of the present study also has a potential implication for the accounting and finance literature. First, there is evidence that cash flows and earnings provide different information. This finding suggests that the cash flow statement and the income statement provide mutually exclusive information. The two statements convey different information in the market. This finding refutes the previous study outcomes that the income information had disseminated in the market prior to the release of cash flow information. Second, cash flows have incremental information content in addition to earnings alone. Again, these findings clearly and strongly refute results of the majority of previous studies from the USA and UK that indicated cash flow data had less information value than that conveyed by earnings. This evidence may also suggest that data reported in the cash flow statement can be a main source of information for decision making, separate from the income statement.

As with all studies, there are inherent limitations and extensions of the present study. First, the present study assumes that the relationship between cash flows and earnings and security returns is a linear function. In this study, the author did not attempt to include non-linear models when addressing hypothesis tests because of the difficulty in determining the type of non-linear equations. However, relaxation of the linear assumption may be warranted in future studies. The work by Ali (1994) could be a good starting point. Second, the present study included only variables of cash flows and earnings. These variables, however, provided low adjusted-R ${ }^{2}$. Accordingly, these models can be extended by including new independent variables for a further investigation. The author did not try to add other variables in the six models because modelling the relationship between cash flows and security returns was not the purpose of the present study. Instead, the study was intended to examine the information content conveyed by cash flow components. Third, the current study assumes that firms that meet the criteria to be included in the study are homogeneous regarding firm size, industry classification and time series. This assumption implied that the behaviour of each firm in the study is identical. For example, small firms have identical share price movements to big firms. Accordingly, future studies may consider these firm characteristics.

\section{References}

Ali, Ashiq, \& Peter F. Pope. (1995). The incremental information Content of Earnings, Fund Flows and Cash Flow: The UK Evidence. Journal of Business Finance and Accounting, 22(1), 19-34.

Ali, Ashiq. (1994). The incremental information Content of Earnings, Working Capital from Operations, and Cash Flows. Journal of Accounting Research, 32(1), p.61-73. http://dx.doi.org/10.2307/2491387

Australian Accounting Standard Board. (1996). 1026: Statement of Cash Flows. In Accounting Handbook.

Ball, R.J., \& P. Brown. (1968). An Empirical Evaluation of Accounting Income Numbers. Journal of Accounting Research. Empirical Research in Accounting: Selected Studies, Autumn, 67-99.

Barlev, B., \& J. Livnat. (1990). The information Content of Funds Statement Ratios. Journal of Accounting, Auditing and Finance, Autumn, 411-431.

Belkaoui, A. (1982). Accrual Accounting and Cash Accounting: Relative Merits of Derived Accounting Numbers. Journal of Business, Finance and Accounting, 299-311. 
Bernard, V. L., \& T. L. Stober. (1989). The Nature and Amount of Information Reflected in Cash Flows and Accruals. The Accounting Review, 64, 624-652.

Biddle, G., G. S. Seow, \& A. F. Siegel. (1995). Relative versus Incremental Information Content. Contemporary Accounting Research, 12(11), Fall, 1-23. http://dx.doi.org/10.1111/j.1911-3846.1995.tb00478.x

Board, J. L. G., \& J. F. S. Day. (1989). The Information Content of Cash Flow Figures. Accounting and Business Research, 20(77), 3-11. http://dx.doi.org/10.1080/00014788.1989.9729389

Bowen, R.M., D. Burgstahler, \& L. A. Daley. (1986, October). Evidence on the Relationship between Earnings and Various Measures of Cash Flow. The Accounting Review, 713-726.

Charitou, A. (1997). The role of cash flows and accruals in explaining security Returns: evidence for the UK. The European Accounting Review, 64, 629-659. http://dx.doi.org/10.1080/09638189700000005

Charitou, A., \& G. Venieris. (1990). The Need for Cash Flow Reporting: Greek Evidence. British Accounting Review, 22, 107-117. http://dx.doi.org/10.1016/0890-8389(90)90057-O

Charitou, A., \& J. E. Ketz. (1990). Valuation of Earnings, Cash Flows and Their Components: An Empirical Investigation. Journal of Accounting, Auditing and Finance, 5(4), Fall, 475-795.

Charitou, A., \& J. E. Ketz. (1991). An Empirical Examination of Cash Flow Measures. ABACUS, 27(1), 51-64. http://dx.doi.org/10.1111/j.1467-6281.1991.tb00256.x

Charitou, A., \& N. Vafeas. (1998). The Association between Operating Cash Flows and Dividend Changes: An Empirical Investigation. Journal of Business Finance and Accounting, 25(1), 5-249.

Cheng, C.S.A., C. S. Liu, \& T. F. Schaefer. (1997). The Value-Relevance of SFAS No. 95 Cash Flows from Operations as Assessed by Security Market Effects. Accounting Horizon, 11(3), 1-15.

Chia, Y.K., R. Czernkowski, \& J. Loftus. (1997). The association of aggregate and disaggregated Earnings with annual stock Returns. Accounting and Finance, 37, 111-128.

Clark, R.S. (1983, February). Statement of Changes in Need of a Change. CA Magazine, 26-30.

Clubb, Collin D.B. (1995). An Empirical Study of the Information Content of Accounting Earnings, Funds Flows and Cash Flows in the UK. Journal of Business Finance and Accounting, 22(1), 35-52.

Collins, D. W., \& S. P. Kothari. (1989). An Analysis of Intertempral and Cross-sectional Determinants of Earning Response Coefficients. Journal of Accounting and Economics, 143-182. http://dx.doi.org/10.1016/0165-4101(89)90004-9

Collins, D. W., S. P. Kothari, \& J. D. Rayburn. (1987). Firm Size and the Information Content of Prices with Respect to Earnings. Journal of Accounting and Economics, 9, 111-138.

Cotter, Julie. (1996). Accrual and Cash Flow Accounting Models: A Comparison of the Value Relevance and Timeliness of Their Components. Accounting and Finance, 36, 127-150.

Dechow, P. (1994). Accounting Earnings and Cash Flows as Measures of Firm Performance: The Role of Accounting Accruals. Journal of Accounting and Economics, 18, 3-42.

Easton, G. P., \& M. Zmijewski. (1989). Cross-Sectional Variation m the Stock Market Response to Accounting Earning Announcement. Journal of Accounting and Economics, 7, 117-142.

Easton, G. P., T. S. Harris, \& J. A. Ohlson. (1992). Aggregate Accounting Earnings Can Explain Most of Security Returns: The Case of Long-Return Intervals. Journal of Accounting and Economics, 15, 119-142. http://dx.doi.org/10.1016/0165-4101(92)90015-T

Garrod, Neil, \& Mahdi, Hadi. (1998, June/July). Investor Response to Cash Flow Information. Journal of Business, Finance and Accounting, 613-631.

Gombola, M. J., \& J. E. Ketz. (1983). A Note on Cash Flow and Classification Pattern of Financial Ratios. The Accounting Review, 1, 105-114.

Harmon, W. K. (1984). Earnings vs. Funds Flows: An Empirical Investigation of Market Reaction. Journal of Accounting, Auditing and Finance, 24-34.

Harrison, W. T., \& C. T. Horngren. (1995). Financial Accounting (Second ed.). Prentice Hall, Englewood Clifts, New Jersey. 
Ingram, R. W., \& T. A. Lee. (1997). Information Provided by Accrual and Cash-Flow Measures of Operating Activities. ABACUS, 33(2), 168-185. http://dx.doi.org/10.1111/1467-6281.00010

Jennings, Ross. (1986). Discussion of the Association of Operating Cash Flow and Accruals With Security Returns. Journal of Accounting Research Supplement, 24, 134-137.

Jones, S., \& J. Ratnatunga. (1997). The Decision Usefulness of Cash Flow Statements By Australian Reporting Entities: Some Further Evidence. British Accounting Review, 29, 67-85. http://dx.doi.org/10.1006/bare.1996.0037

Jones, S., \& L. Widjaja. (1998). The Decision of Cash-Flow Information- A note. ABACUS, 34(2), 204-219. http://dx.doi.org/10.1111/1467-6281.00030

Jones, S., C. Romano, \& K. Smyrnios. (1995). An Evaluation of Decision Usefulness of Cash Flow Statements by Australian Reporting Entities. Accounting and Business Research, 25(98), 115-129.

Ketz, J.E., \& J. A. Largay. (1987, June). Reporting Income and Cash Flows from Operation. Accounting Horizons, l(2), 9-17.

Ketz, J.E., \& R.F. Kochanek. (1983, July). Fund Flow Statements. Financial Executive, 34-41.

Largay, J. A., \& C. P. Stickney. (1980, July/August). Cash Flows, Ratio Analysis and the W. T. Grant Bankruptcy. Financial Analyst Journal, 50-54.

Lev, B., \& J. A. Ohlson. (1982). Market-Based Empirical Research m Accounting: A Review, Interpretation, and Extension. Journal of Accounting Research, 20(supplement), 249-321.

Lipe, R. C. (1986). The Information Contained in the Components of Earnings. Journal of Research, 24, 38-64.

Livnat, J., \& Paul Zarowin. (1990). The Incremental Information Content of Cash Flow Components. Journal of Accounting and Economics, 13, 25-46. http://dx.doi.org/10.1016/0165-4101(90)90066-D

Raybum, J. (1986). The Association of Operating Cash Flow and Accruals with Security Returns. Journal of Accounting Research, 24, 12-38.

Reinganum, M. R. (1981, March). Misspecification of Capital Asset Pricing Empirical Anomalies Based on Earnings' Yields and Market Values. Journal of Financial Economics, 9, 19-46.

Schaefer, T., \& Michael Kennelley. (1986). Alternative Cash Flow Measures and Risk-Adjusted Returns. Journal of Accounting, Auditing and Finance, 278-287.

Seng, Dyna. (1996, October). Accrual versus Cash Flows. Chartered Accountant Journal, 33-35.

Simons, Katheleen. (1992). The Relationship Between Dividend Changes and Cash Flows: An Empirical Analysis. Journal of Business Finance and Accounting, 21(4), 577-587. http://dx.doi.org/10.1111/j.1468-5957.1994.tb00337.x

Smail, B. E., \& M. K. Kim. (1989, January). On the Association of Cash Flow Variables with Market Risk: Further Evidence. The Accounting Review, 125-136.

Swanson, E.P, \& R. Vangermeersch. (1981, November). The Statement of Financing and Investing Activities. CPA Journal, 32-39.

Wang, Z., \& John Eichenseher. (1998). Informativeness and Predictability of Cash Flows. Journal of Applied Business Research, 14(2), 21-32.

Wilson, G. P. (1986). The Relative Information Content of Accruals and Cash Flows: Combined Evidence at the Earnings Announcement and Annual Report Date. Journal of Accounting Research, 24, 165-200. http://dx.doi.org/10.2307/2490736

Wilson, G. P. (1987). The Incremental Information Content of the Accrual and Funds Components of Earnings after Controlling for Earnings. The Accounting Review, 62, 293-321. 